CONF- $950412--53$

UCRL-JC-120314

PREPRINT

\title{
Lithium Intercalation in Porous Carbon Electrodes
}

\author{
T. D. Tran \\ J. Feikert \\ R. W. Pekala \\ J. Miller \\ B. Dunn
}

This paper was prepared for submittal to the Material Research Society 1995 Spring Meeting

San Francisco, CA

April 17-21, 1995

April 1995

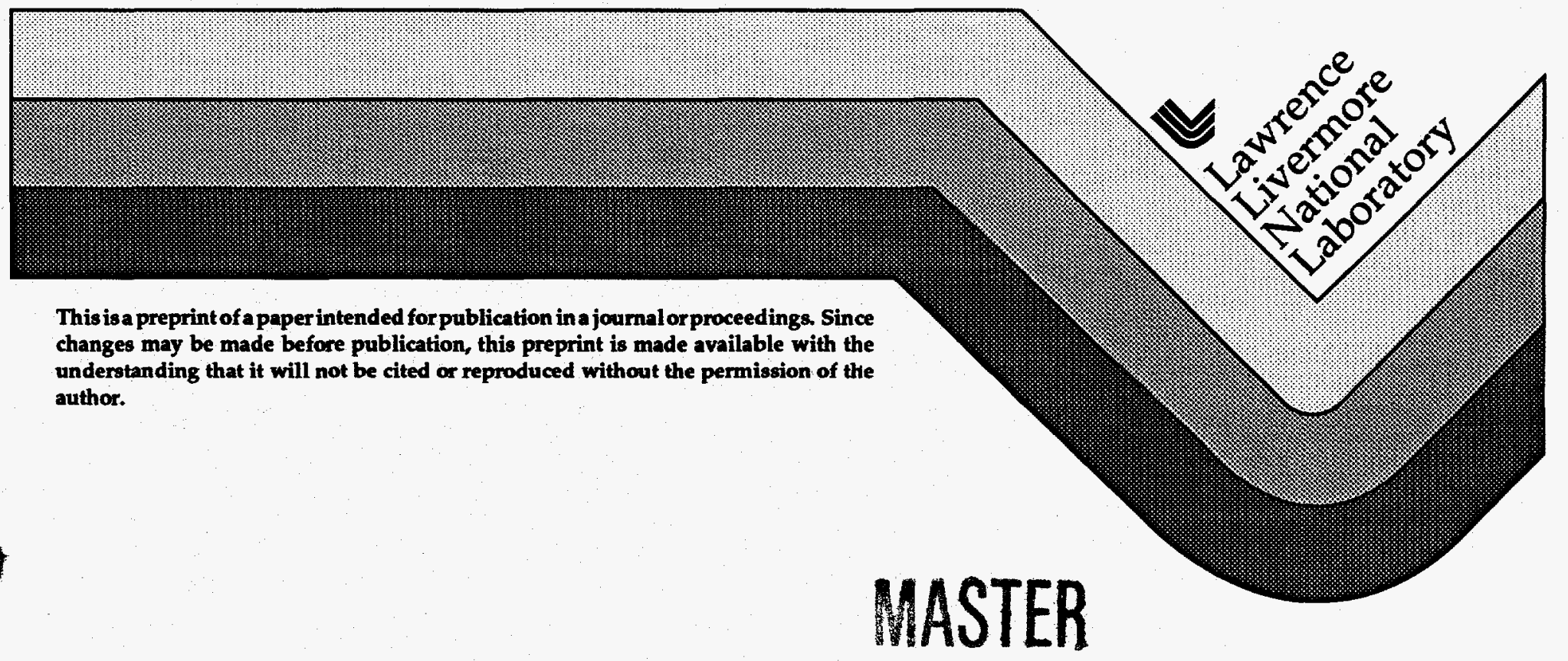

DISTRIBUTION OF THIS DOCUMENT IS UNLWUETES BS 


\section{DISCLAIMER}

This document was prepared as an account of work sponsored by an agency of the United States Government. Neither the United States Government nor the University of California nor any of their employees, makes any warranty, express or implied, or assumes any legal liability or responsibility for the accuracy, completeness, or usefulness of any information, apparatus, product, or process disclosed, or represents that its use would not infringe privately owned rights. Reference herein to any specific commercial products, process, or service by trade name, trademark, manufacturer, or otherwise, does not necessarily constitute or imply its endorsement, recommendation, or favoring by the United States Government or the University of California. The views and opinions of authors expressed herein do not necessarily state or reflect those of the United States Government or the University of California, and shall not be used for advertising or product endorsement purposes. 


\section{DISCLAIMER}

Portions of this document may be illegible in electronic image products. Images are produced from the best available original document. 


\title{
LITHIUM INTERCALATION IN POROUS CARBON ELECTRODES
}

\author{
T. D. TRAN, J. FEIKERT, R. W. PEKALA, J. MILLER* AND B. DUNN* \\ Chemistry \& Materials Science Department \\ Lawrence Livermore National Laboratory \\ Livermore, CA 94550 \\ *Department of Materials Science and Engineering \\ University of California-Los Angeles, \\ Los Angeles, CA 90024
}

\begin{abstract}
Carbons derived from the phase separation of polyacrylonitrile/solvent mixtures were investigated as lithium intercalation anodes for rechargeable lithium-ion batteries. The carbon electrodes have a bulk density of $0.35-0.5 \mathrm{~g} / \mathrm{cm}^{3}$, relatively low surface areas $\left(<10 \mathrm{~m}^{2} / \mathrm{g}\right)$, and micron-size cells. Pyrolysis temperature influences the reversible lithium intercalation and the irreversible capacity (associated with the formation of the passivating layer). Carbon electrodes pyrolyzed at $600^{\circ} \mathrm{C}$ have first-cycle capacity as high as $550 \mathrm{mAh} / \mathrm{g}$ as well as large irreversible capacity, $440 \mathrm{mAh} / \mathrm{g}$. Electrodes prepared at $1050^{\circ} \mathrm{C}$ have reversible capacities around 270 $\mathrm{mAh} / \mathrm{g}$ with relatively lower capacity losses $(120 \mathrm{mAh} / \mathrm{g})$. Doping the organic precursors with phosphoric acid, prior to pyrolysis at $1050^{\circ} \mathrm{C}$, leads to carbon electrodes with reversible capacities as high as $450 \mathrm{mAh} / \mathrm{g}$. The capacity of doped carbon increased with increasing phosphorus concentration in the samples. The doped carbon anodes exhibited good cycleability and excellent coulombic efficiency. The electrochemical performance is related to morphology, chemical composition, and local structural order.
\end{abstract}




\section{INTRODUCTION}

A variety of carbonaceous materials (petroleum cokes, carbon blacks, carbon fibers, graphites, etc.) have been investigated as lithium intercalation anodes for lithium-ion or rockingchair rechargeable cells $[1,2,3]$. Many of these types of materials have capacity below the theoretical value of $372 \mathrm{mAh} / \mathrm{g}$ which corresponds to 1 mole of lithium per 6 moles of carbon $\left(\mathrm{LiC}_{6}\right)$. Recently, several types of carbons prepared from polymeric precursors at temperatures below $1000^{\circ} \mathrm{C}$ were shown to have capacities significantly higher than $\mathrm{LiC}_{6}$. Carbon electrodes obtained from carbonized petroleum pitches $[4,5,6]$, polyparaphenylene [7], epoxy resin [5], phenolic resin [8] had capacities as large as $1000 \mathrm{mAh} / \mathrm{g}$. Dahn and co-workers $[4,5]$ relate the high capacity of these materials to the residual hydrogen content in the carbons. The capacities of carbons doped with phosphorus were also demonstrated to exceed $\mathrm{LiC}_{6}$. Omaru and co-workers $[9,10]$ have shown that the presence of phosphorus in their polyfurfuryl alcohol-based carbons enhanced the electrode capacity by as much as $30 \%$ (to $450 \mathrm{mAh} / \mathrm{g}$ ). Work in our laboratory with various types of phosphorus-doped commercial cokes and polyacrylonitrile-derived carbons also showed increased capacities [11, 12,13]. In this paper, we discuss recent results on both the effect of pyrolysis temperature and the influence of a phosphorus additive on the ability of polyacrylonitrile-derived carbons to intercalate lithium. This work is part of a continuing effort directed at developing an understanding of how electrode morphology, chemical composition and local structural order affect electrochemical performance $[11,12,13]$.

\section{EXPERIMENTAL}

Porous carbon electrodes were prepared as follows. Polyacrylonitrile (PAN Type A; Dupont) was dissolved in a 97:3 mixture of dimethylsulfoxide/water at elevated temperature in a closed vessel. This slightly yellow solution was then poured over a piece of carbon paper (grade 50; Lydall Corp) lying on a copper plate. A pre-heated glass plate was used to cover the carbon paper and uniformly spread the PAN solution. The copper plate was then placed in contact with an ethanol slush bath at $-80^{\circ} \mathrm{C}$ to induce phase separation and freeze the solvent mixture. The frozen PAN/carbon paper composite was then placed in methanol and allowed to warm to room temperature. After several solvent exchanges with fresh methanol, the specimens were dried in a circulating oven at $50-85^{\circ} \mathrm{C}$. In phosphorus doping experiments, the composite was soaked in a phosphoric acid/methanol solution prior to drying. All specimens were then pyrolyzed in a flowing nitrogen atmosphere for 4 hours at a final temperature of $600-1050{ }^{\circ} \mathrm{C}$ using a ramp cycle of $\sim 1^{\circ} \mathrm{C} / \mathrm{min}$. The presence of the Lydall carbon paper prevented the large amounts of macroscopic shrinkage normally associated with the pyrolysis of PAN foams [14]. 
The electrochemical experiments were carried out in $15 \mathrm{ml}$, three-electrode cylindrical cells in which the electrodes and separators were positioned horizontally and stacked vertically. The geometric surface area of the working electrode was $1.12 \mathrm{~cm}^{2}$. Lithium foils (Cyprus Foote Mineral) were used as the counter and reference electrodes. Whatman fiberglass filters (934-AH) were used as separators between the working and counter electrodes. The electrolyte was $0.05 \mathrm{M}$ $\mathrm{LiAsF}_{6}$ (FMC Corp) and $0.45 \mathrm{M}$ lithium trifluoromethanesulfonimide, $\mathrm{LiN}\left(\mathrm{CF}_{3} \mathrm{SO}_{2}\right)_{2}$, (tradename HQ115, 3M Corp) in propylene carbonate (Grant Chemical). The cells were assembled and tested at $16 \pm 2{ }^{\circ} \mathrm{C}$ in a dry argon-atmosphere glove box ( $<10 \mathrm{ppm}$ water). Charge/discharge studies were performed using a 64-channel Maccor battery tester. The cell was charged at a constant-current rate corresponding to 1 mole of lithium per 6 moles of carbon in 24 hours $(\mathrm{C} / 24)$ to a cut-off voltage of $0.005 \mathrm{~V}\left(\mathrm{Li}^{+} / \mathrm{Li}\right)$ and held at this potential for 4 hours. It was then discharged at the same rate to $1.5 \mathrm{~V}$ and held there for another 4 hours. This procedure was used to assure complete lithium intercalation/deintercalation. After 4 cycles, the rate was increased to C/8 (i.e., 1 mole of Li per 6 moles of carbon in 8 hours) for further cycle life study.

XPS spectra between 0 and $700 \mathrm{eV}$ were taken using a Kratos X-ray photoelectron spectrometer at a scan speed of $1 \mathrm{eV} / \mathrm{sec}$. Spectra near $\mathrm{C}, \mathrm{O}$, and $\mathrm{P}$ peaks were obtained using a slower scan speed of $0.167 \mathrm{eV} / \mathrm{sec}$. The step size for all scans was $1 \mathrm{eV} / \mathrm{step}$. The quantitative analysis of the XPS spectrum was done [15] to determine the phosphorus concentration. SEM observations were performed using a Hitachi S570 Scanning Electron Microscope.

\section{RESULTS AND DISCUSSION}

The porous carbon electrodes selected for use as lithium intercalation electrodes have bulk density between 0.35 to $0.5 \mathrm{~g} / \mathrm{cc}$ and low BET surface areas, typically less than $10 \mathrm{~m}^{2} / \mathrm{g}$. The low surface areas minimize the first cycle irreversible capacity loss associated with the formation of a passivating film at the carbon/electrolyte interface. SEM observations (Figure 1) show that the carbon/fiber composite consists of interwoven sheets (1-5 $\mu \mathrm{m}$-thick) of pyrolyzed PAN and carbon fibers. The PAN structure is relatively non-porous while the fibrous matrix provides porous structure (voids) on the order of several microns.

The potential-capacity profiles for the intercalation and de-intercalation of $\mathrm{Li}$ in carbonized PAN anodes prepared at various pyrolysis temperatures are presented in Figure 2. Lithium intercalation occurs over a broad range of potentials. Deintercalation from the lowtemperature samples $\left(<900^{\circ} \mathrm{C}\right)$ takes place with a steeper slope (compared to the intercalation profile) and has a near linear profile between 0 to $1.5 \mathrm{~V}$. The total discharge capacity for these materials decreases with increasing pyrolysis temperature as can be seen from the figure. The PAN-derived carbons prepared at $600^{\circ} \mathrm{C}$ (designated as PAN600) has capacity exceeding 550 


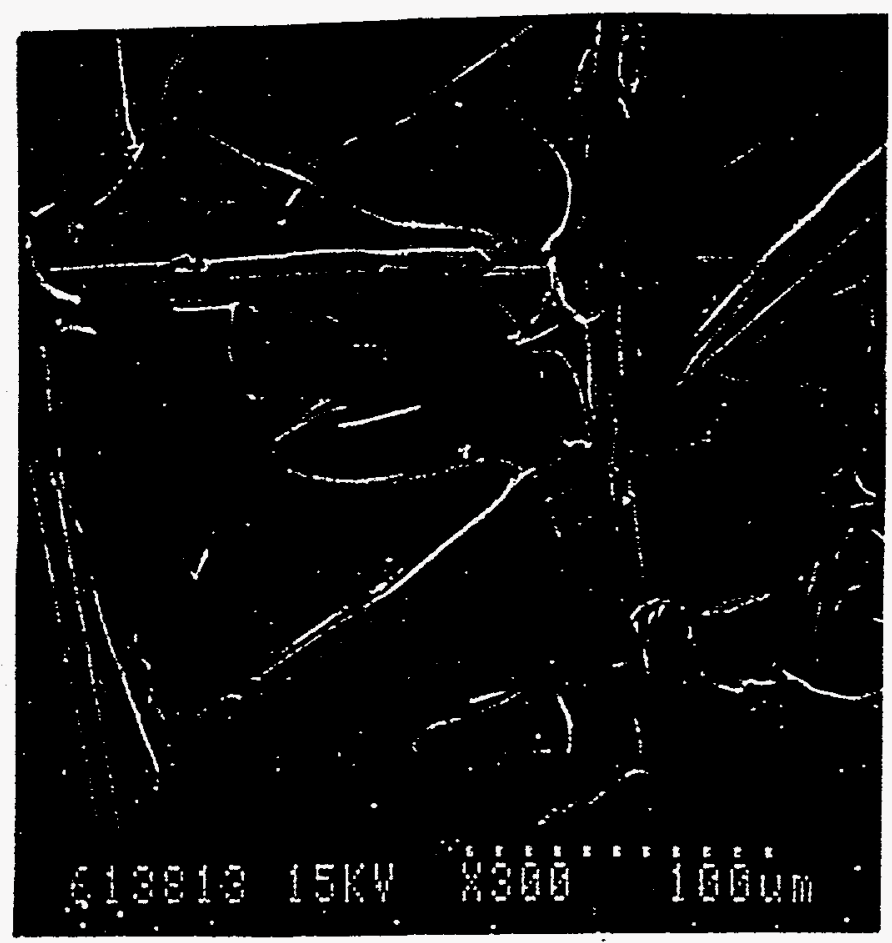

Figure 1. Scanning electron micrograph of a phosphorus-doped PAN carbon

$\mathrm{mAh} / \mathrm{g}$ while that for carbons pyrolyzed at $1050^{\circ} \mathrm{C}$ (PAN1050) is $270 \mathrm{mAh} / \mathrm{g}$. The irreversible capacity loss during the first cycle is the difference between the charge capacity and the discharge capacity. This value is $450 \mathrm{mAh} / \mathrm{g}$ for PAN600. The capacity loss decreases with increasing pyrolysis temperature. For samples prepared at $1050^{\circ} \mathrm{C}$, the capacity loss is 120 $\mathrm{mAh} / \mathrm{g}$.

The work of Dahn et al. and others [3-8] provides motivation to investigate the combined effect of low temperature pyrolysis and phosphorus doping. The effect of phosphorus doping on the performance of carbonized PAN materials prepared at $1050^{\circ} \mathrm{C}$ was discussed earlier [13] and is reviewed in Figure 3. The potential for de-intercalation, at a given capacity, is lower for the phosphorus-doped carbon and will provide lithium-ion cells with a higher average cell voltage. A comparison of the profiles of undoped versus doped carbonized PAN prepared at $600^{\circ} \mathrm{C}$ is included in Figure 3. The discharge/charge curves look similar. They have first-cycle discharge capacity around $550 \mathrm{mAh} / \mathrm{g}$. The irreversible capacities for these materials are significant, 380 $\mathrm{mAh} / \mathrm{g}$. 


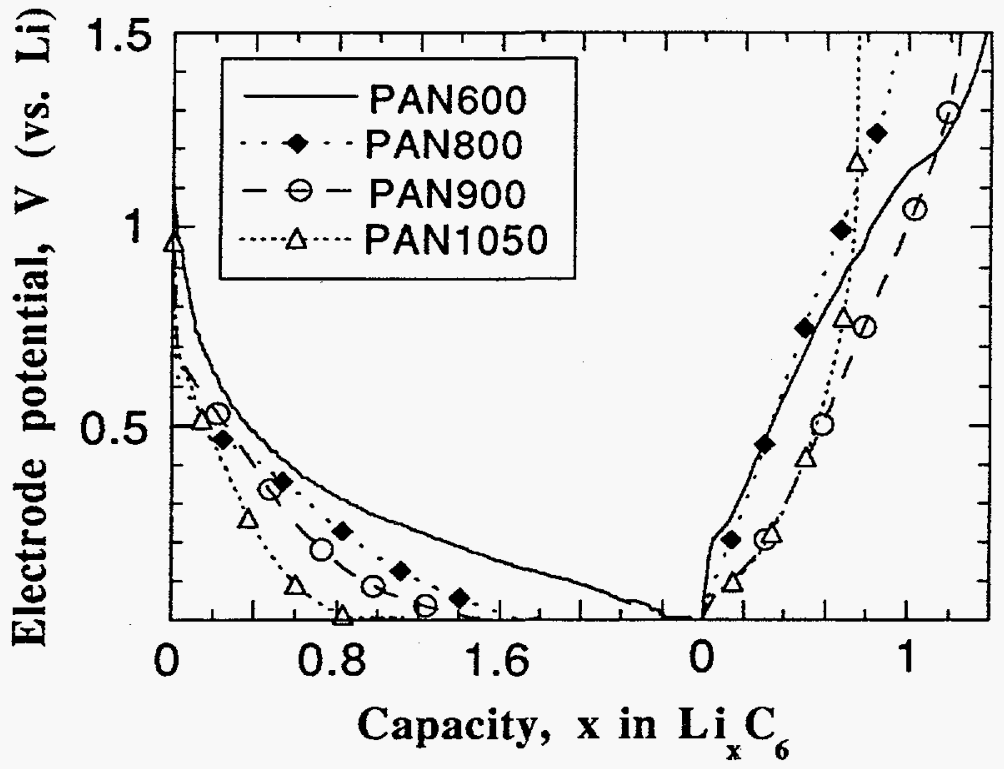

Figure 2. Discharge/charge voltage versus capacity for the first cycles of PAN-derived carbons pyrolyzed at various temperatures. Electrolyte, $0.05 \mathrm{M} \mathrm{LiAsF}_{6}, 0.45 \mathrm{M} \mathrm{LiN}\left(\mathrm{CF}_{3} \mathrm{SO}_{2}\right)_{2}$ in $\mathrm{PC} . \mathrm{C} / 24$ rate. $\mathrm{T}, 16^{\circ} \mathrm{C}$.

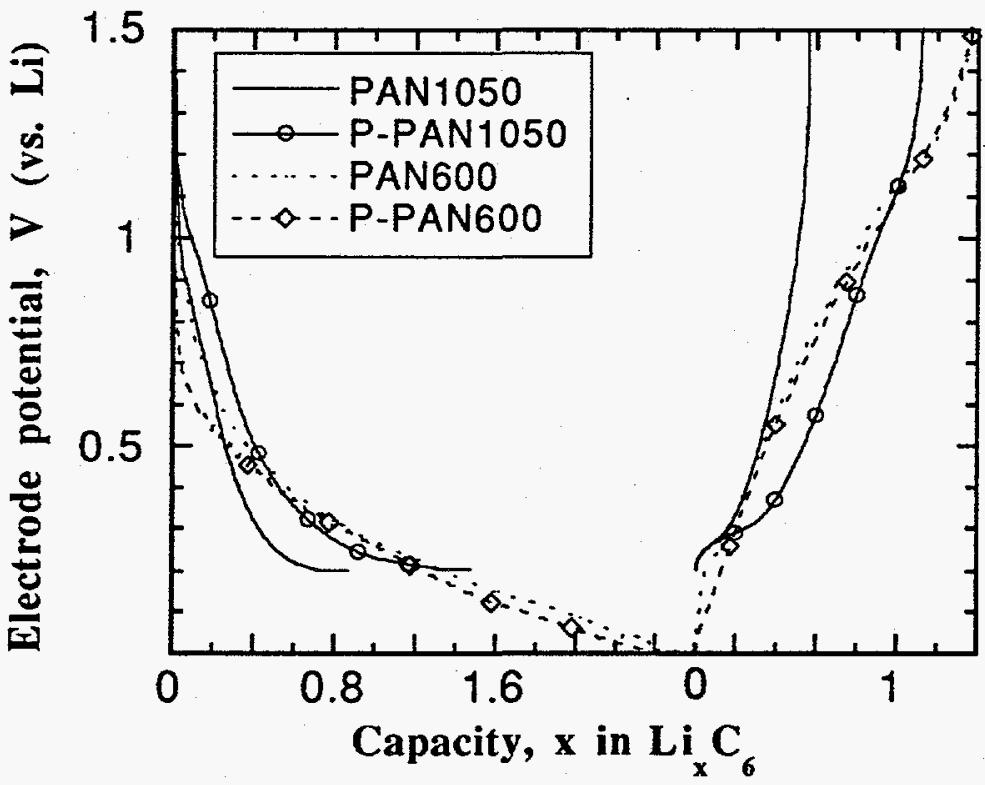

Figure 3. Comparison of first-cycle discharge/charge profiles of undoped versus doped carbons pyrolyzed at various temperatures. Curves for PAN1050 and P-PAN1050 are shifted up (along y-axis) by $0.2 \mathrm{~V}$ for clarity. Electrolyte, $0.05 \mathrm{M} \mathrm{LiAsF}_{6}, 0.45 \mathrm{M}$ $\mathrm{LiN}\left(\mathrm{CF}_{3} \mathrm{SO}_{2}\right)_{2}$ in $\mathrm{PC}$. $\mathrm{C} / 24$ rate. $\mathrm{T}, 16^{\circ} \mathrm{C}$. 
The effect of $\mathrm{H}_{3} \mathrm{PO}_{4}$ treatment on phosphorus content was investigated by X-ray photoelectron spectroscopy. Figure 4 shows a characteristic XPS spectrum of a phosphorus doped PAN-derived carbon. Comparison of the relative peak areas for phosphorus and carbon in the doped samples shows that the effective phosphorus content increases with $\mathrm{H}_{3} \mathrm{PO}_{4}$ concentration in the doping solution. Data from the area ratios of $\mathrm{P}_{2 \mathrm{~s}} / \mathrm{C}_{1 \mathrm{~s}}$ and $\mathrm{P}_{2 \mathrm{p}} / \mathrm{C}_{1 \mathrm{~s}}$ show the same trend.

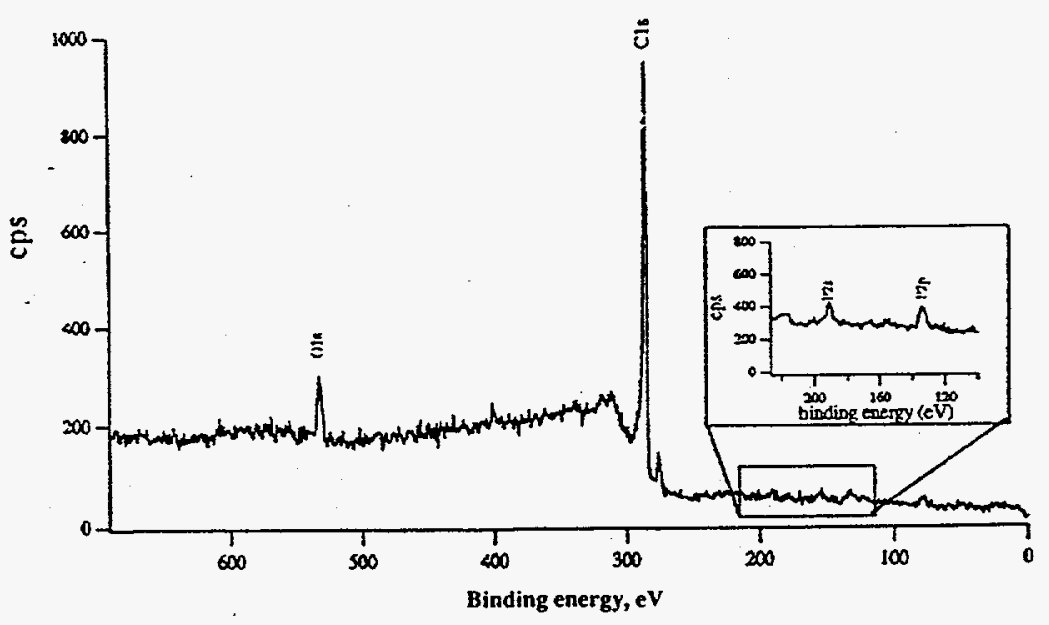

Figure 4. Representative XPS spectrum of PAN-based carbon doped with 3.26 at.\% phosphorus

The variation in the lithium-intercalation capacity with the phosphorus content is shown in Figure 5. The reversible capacity of doped carbon anodes increases with increasing phosphorus concentration. The first-cycle capacity loss associated with passivated film formation decreases with increasing phosphorus content. Electrodes containing $>2$ atomic\% phosphorus have reversible capacities in the range of $450 \mathrm{mAh} / \mathrm{g}$ with relatively low capacity losses $(<110 \mathrm{mAh} / \mathrm{g})$. The undoped and doped PAN-derived carbon anodes prepared at $1050^{\circ} \mathrm{C}$ have been shown $[11,13]$ to exhibit excellent cycle-life performance with coulombic efficiency greater than $99 \%$. These electrodes have been cycled for over 100 cycles in our laboratory with less than $10 \%$ drop in reversible capacity. Despite the enhanced capacities obtained with lowtemperature carbons, these capacities drop by as much as $30 \%$ in subsequent cycles. This phenomenon has been discussed earlier [5].

The presence of phosphorous in the samples treated at $600^{\circ} \mathrm{C}$ did not appear to have any advantageous effect on the carbon electrochemical performance. The presence of hydrogen or 
related effects may dominate the electrochemical behavior of these low temperature materials as suggested by Dahn and co-workers [4,5]. Additional experiments are being carried out to investigate this effect. Since most hydrogen is eliminated at temperatures above $1000^{\circ} \mathrm{C}$, the enhanced effect of phosphorous doping for samples prepared at $1050^{\circ} \mathrm{C}$ is clear. The physical and chemical nature of phosphorus, however, is not well understood. Further work is needed to delineate the role of phosphorus in lithium intercalation.

\section{ACKNOWLEDGMENT}

The authors would like to thank Professor R. S. Williams (UCLA) for his assistance with the acquisition and interpretation of the XPS data. This work was performed under the auspices of the US Department of Energy by Lawrence Livermore National Laboratory under contract \# W-7405-ENG-48, with financial support from the Office of Basic Energy Sciences - Division of Advanced Energy Projects and Division of Chemical Sciences.

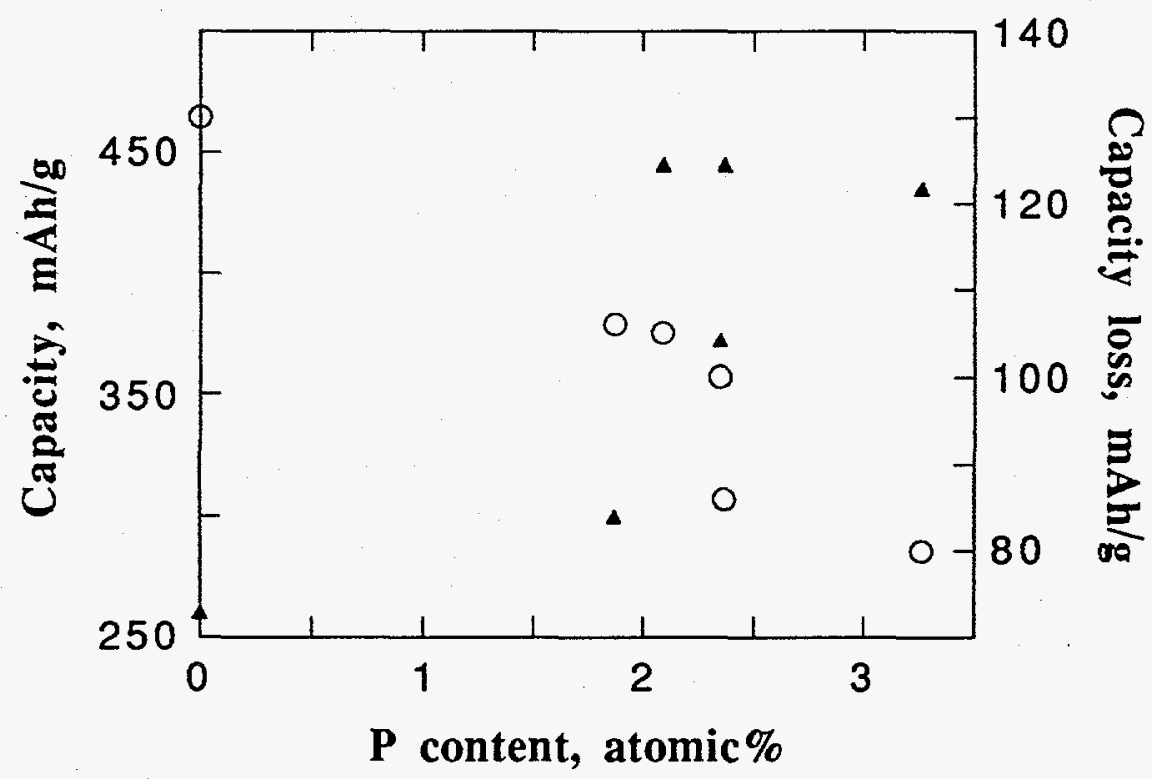

Figure 5. Capacity and irreversible capacity loss (first cycle) as a function of $P$ content. Electrolyte, $0.05 \mathrm{M} \mathrm{LiAsF} 6,0.45 \mathrm{M} \mathrm{LiN}\left(\mathrm{CF}_{3} \mathrm{SO}_{2}\right)_{2}$ in $\mathrm{PC}$. Rate, $\mathrm{C} / 24 . \mathrm{T}, 16^{\circ} \mathrm{C}$. 


\section{REFERENCES}

1. See papers presented at the 7th International Meeting on Lithium Batteries, Boston, MA, May 15-20 (1994).

2. See papers presented at the 186th Meeting of the Electrochemical Society, Miami Beach, Fl, October 9-14 (1994).

3 J. Dahn, A. Sleigh, H. Shi, B. Way, W. Weydanz, J. Reimers, Q. Zhong and U. von Sacken, in Lithium Batteries New Materials, Developments and Perspectives, G. Pistoia, Editor, Elsevier, Amsterdam, The Netherlands, p. 1 (1994).

4. J. R. Dahn, Abstract \# 132, 186th Meeting of the Electrochemical Society, Miami Beach, Fl, October 9-14 (1994).

5. Tao Zheng, Y. Liu, E. W. Fuller, S. Tseng, U. von Sacken and J. R. Dahn, submitted to J. Electrochem. Soc. (1995).

6. A. Mabuchi, K. Tokumitsu, H. Fujimoto and T. Kasuh, 7th International Meeting on Lithium Batteries, Boston, Massachusetts, May 15-20 (1994).

7. K. Sato, M. Noguchi, A. Demachi, N. Oki and M. Endo, Science 264, 556 (1994).

8. S. Yata, H. Kinoshita, M. Komori, N. Ando, T. Kashiwamura, T. Harada, K. Tanaka and T. Yamabe, Synthetic Metals 62, 153 (1994).

9. A. Omaru, H. Azuma, M. Aoki, A. Kita, and Y. Nishi, in Proceedings of the Symposium on Lithium Batteries, S. Surampudi and V Kock, eds., The Electrochemical Society, Inc., Pennington, NJ, p. 21 (1993).

10. A. Omaru, H. Azuma, M. Aoki, A. Kita, and Y. Nishi, Abstract \#25, 182nd Meeting of The Electrochemical Society, Toronto, Canada (1992).

11. S. T. Mayer, J. H. Feikert, T. D. Tran, J. L. Kaschmitter and R. W. Pekala, Abstract 1-B-31, 7th International Meeting on Lithium Batteries, Boston, MA, May 15-20 (1994). 
12. T. D. Tran, J. H. Feikert, S. T. Mayer, X. Song and K. Kinoshita. Abstract No. 88, The 186th Meeting of the Electrochemical Sociey, Miami Beach, FL, October 9-14 (1994).

13. T. D. Tran, S. T. Mayer and R. W. Pekala, The Fall 1994 Meeting of The Materials Research Society, November 28-December 2 (1994).

14. A. P. Sylwester, J. H. Aubert, P. B. Rand, C. Arnold, Jr. and R. C. Clough, Am. Chem. Soc. PMSE Preprint, 57, 113 (1987).

15. G. C. Smith, Surface Analysis of Electron Spectroscopy, Measurement and Interpretation, Plenum Press (1994). 